\title{
Male infertility and COVID-19: Is there a relationship?
}

\author{
Infertilidade masculina e COVID-19: Há alguma relação? \\ Infertilidad masculina y COVID-19: ¿Existe una relación?
}

Received: 05/13/2021 | Reviewed: 05/19/2021 | Accept: 05/20/2021 | Published: 06/07/2021

\author{
Alyne Barreto Mesquita de Goés \\ ORCID: https://orcid.org/0000-0001-5187-6174 \\ Liga Norte Riograndense Contra o Câncer, Brazil \\ E-mail: alynebarreto2@hotmail.com \\ Irami Araújo-Neto \\ ORCID: https://orcid.org/0000-0003-3360-2991 \\ Liga Norte Riograndense Contra o Câncer, Brazil \\ E-mail: irami.neto@uol.com.br \\ Natália Marcelino Araújo \\ ORCID: https://orcid.org/0000-0003-3143-6299 \\ Liga Norte Riograndense Contra o Câncer, Brazil \\ E-mail: nataliamarcelino4@gmail.com \\ Pedro Vilar de Oliveira Villarim \\ ORCID: https://orcid.org/0000-0002-9504-8589 \\ Liga Norte Riograndense Contra o Câncer, Brazil \\ E-mail: pedrovilar@ufrn.edu.br \\ Thais Cristina Loyola da Silva \\ ORCID: https://orcid.org/0000-0003-1605-9923 \\ Liga Norte Riograndense Contra o Câncer, Brazil \\ E-mail: thaiscristinaloyola@outlook.com \\ Camila Vilar de Oliveira Villarim \\ ORCID: https://orcid.org/0000-0002-3173-7932 \\ Liga Norte Riograndense Contra o Câncer, Brazil \\ E-mail: camilavillarim@gmail.com \\ Amália Cinthia Meneses Rêgo \\ ORCID: https://orcid.org/0000-0002-0575-3752 \\ Universidade Potiguar, Brazil \\ E-mail: amalia.rego@liga.org.br \\ Irami Araújo-Filho \\ ORCID: https://orcid.org/0000-0003-2471-7447 \\ Universidade Potiguar, Brazil \\ Universidade Federal do Rio Grande do Norte, Brazil
}

Instituto de Ensino, Pesquisa e Inovação da Liga Contra o Câncer, Brazil

Instituto de Ensino, Pesquisa e Inovação da Liga Contra o Câncer, Brazil

E-mail: irami.filho@uol.com.br

\begin{abstract}
In the testicles, the expression of Angiotensin-Converting Enzyme 2 receptors makes it more susceptible to infection by Sars-CoV-2 and, therefore, to male infertility with significant health problems for the patient. Therefore, this study aimed to analyze the clinical pathophysiology and the mechanisms involved in the genesis of male infertility from COVID-19, through the critical analysis of the main scientific evidence on the subject presented so far. From an integrative review of the literature containing 30 studies selected using inclusion criteria in the period 2020-2021, the direct and indirect impacts on male fertility in pathophysiological and psychosocial terms were observed in this study, in addition to therapeutic options, guidelines host and efficient semiological approach. Thus, the impact of the pandemic, even after one year, is immeasurable. Additional studies to reveal the real consequences and the mechanism by which the disease can affect male fertility are still needed. It is essential to pay more attention to male genital exams in patients with COVID-19. The psychobiological consequences of the pandemic in infertile patients should not be underestimated.
\end{abstract}

Keywords: COVID-19; COVID-19 virus disease; COVID-19 virus infection; SARS-CoV-2; Male infertility; Reproductive health.

\section{Resumo}

Nos testículos, a expressão de receptores da Enzima Conversora de Angiotensina 2, torna mais suscetível à infecção pelo Sars-CoV-2 e por conseguinte, à infertilidade masculina com significativos agravos à saúde do paciente. Por isso, este estudo objetivou analisar a fisiopatologia clínica e os mecanismos envolvidos na gênese da infertilidade masculina 
proveniente da COVID-19, através da análise crítica das principais evidências científicas sobre o assunto apresentadas até o momento. A partir de uma revisão integrativa da literatura contendo 30 estudos selecionados mediante critérios de inclusão no período de 2020-2021, observou-se no presente estudo os impactos diretos e indiretos sobre a fertilidade masculina em termos fisiopatológicos e psicossociais, além de opções terapêuticas, orientações de acolhimento e abordagem semiológica eficiente. Dessa forma, o impacto da pandemia, mesmo após um ano, é imensurável. Estudos adicionais para revelar as reais consequências e o mecanismo pelo qual a doença pode afetar a fertilidade masculina ainda são necessários. É fundamental oferecer mais atenção aos exames genitais masculinos em pacientes portadores de COVID-19. As consequências psicobiológicas da pandemia em pacientes inférteis não devem ser subestimadas.

Palavras-chave: COVID-19; Doença por vírus COVID-19; Infecção por vírus COVID-19; SARS-CoV-2; Infertilidade masculina; Saúde reprodutiva.

\section{Resumen}

En los testículos, la expresión de los receptores de la enzima convertidora de angiotensina 2 lo hace más susceptible a la infección por Sars-CoV-2 y, por tanto, a la infertilidad masculina con importantes problemas de salud para el paciente. Por tanto, este estudio tuvo como objetivo analizar la fisiopatología clínica y los mecanismos implicados en la génesis de la infertilidad masculina por COVID-19, a través del análisis crítico de las principales evidencias científicas sobre el tema presentadas hasta el momento. A partir de una revisión integradora de la literatura que contiene 30 estudios seleccionados con criterios de inclusión en el período 2020-2021, se observaron en este estudio los impactos directos e indirectos sobre la fertilidad masculina en términos fisiopatológicos y psicosociales, además de las opciones terapéuticas, guías hospedantes y eficientes. enfoque semiológico. Por lo tanto, el impacto de la pandemia, incluso después de un año, es inconmensurable. Aún se necesitan estudios adicionales para revelar las consecuencias reales y el mecanismo por el cual la enfermedad puede afectar la fertilidad masculina. Es fundamental prestar más atención a los exámenes genitales masculinos en pacientes con COVID-19. Las consecuencias psicobiológicas de la pandemia en pacientes infértiles no deben subestimarse.

Palabras clave: COVID-19; Enfermedad por virus COVID-19; Infección por el virus COVID-19; SARS-CoV-2; Infertilidad masculina; Salud reproductiva.

\section{Introduction}

In December 2019, Sars-CoV-2, known as the new Coronavirus or COVID-19, appeared in China, declared by the World Health Organization (WHO) as responsible for a new pandemic in March 2020, causing severe respiratory failure, a response systemic inflammatory, multiple organ dysfunctions, death and even infertility (Dutta et al., 2021).

The virus is transmitted interpersonally by droplets, with greater prevalence, susceptibility and lethality in males. In the human body, cells that express receptors for Angiotensin-Converting Enzyme 2 (ACE2) are predisposed to infection by SarsCoV-2 (Illiano et al., 2020).

In the case of male fertility, since the testicles, specifically Leydig and Sertoli cells, have one of the highest amounts of ACE2 among the various tissues of the body, the testicular expression of ACE2 was shown to be related to age, affecting individuals 20-30 years, while those over 60 have lower levels of expression (Illiano et al., 2020; Fu J et al., 2020).

In the context of male reproduction, Sars-CoV-2 activates sensitive pathways through inflammatory responses with the release of cytokines, induces oxidative stress and affects semen quality, in addition to causing orchitis and psychological stress, the main causes of male infertility (Olaniyan et al., 2020; Dutta et al., 2021) .

Reproductive health in humans depends on a good quality of life, physical, mental and social well-being. The current pandemic status of COVID-19, including treatment, prevention and control measures, alters the patient's perception of the disease, promotes panic, depression, anxiety, fear, post-traumatic stress disorders and, consequently, affects reproductive health (Li et al., 2020; Esposito et al., 2020).

In this sense, the present review analyzed the clinical pathophysiology and interference in male infertility from COVID-19, since such an approach requires extensive discussion and scientifically validated responses. 


\section{Methodology}

The research was carried out through an integrative literature review in search of current evidence on the relationship between male infertility and COVID-19. The databases PubMed/Medline, Scopus, Scielo, Embase, Web of Science and Google Scholar were used, known as gray literature. Studies related to male infertility and the new coronavirus were selected, through the combination of indexes present in the MeSH Platform (Medical Subject Headings) - PubMed/Medline: COVID-19; COVID19 Virus Disease; COVID-19 Virus Infection; SARS-CoV-2; Male Infertility; Reproductive Health. Relevant studies published between 2020-2021, carried out in humans, male, in the cohort modalities, systematic review, case-control, cross-sectional, case series and randomized clinical trials were included, totaling 30 articles. The analysis, review and selection of articles were carried out in pairs, in a blind and separate way, based on the reading of the title and abstract, with a third reviewer in case of disagreement. Studies that addressed other topics, did not have a full text or at least one keyword in the title and abstract, were excluded from the research (Pereira et al., 2018).

\section{Results}

In total, 58 studies on the topic were initially found. After applying the exclusion criteria, 30 manuscripts remained, which were read, analyzed and reviewed in detail and therefore included in this review.

In agreement with the literature, the serious global threat that the pandemic by COVID-19 became evident and the close relationship of ACE2 in the infection by Sars-CoV-2, especially in the context of male infertility.

Evidently, it is a delicate issue, which causes significant direct and indirect impacts in pathophysiological and psychosocial terms, as well as influencing the individual's conduct as a person who belongs and lives in society.

In this sense, an efficient semiological approach, reception and thorough investigation as a prophylactic or therapeutic attitude are necessary. It is important to identify possible consequences in the short, medium and long term, to minimize individual and collective damages.

The scientific evidence found demonstrated the need for more robust evidence on the involvement of Sars-CoV-2 in the male reproductive system. Thus, the speed in researching in this context is notorious, due to the increase in male infertility during and after being affected by the disease.

\section{Discussion}

\section{Viral infection}

The importance of viral infections associated with the male reproductive system has been highlighted in several studies, leading to the detection of more than 30 viruses that spread in the semen, such as mumps, human immunodeficiency, hepatitis and zika that cross the blood-testicular barrier, causing as orchitis, epididymitis and changes in sperm count or semen quality as a whole (Sheikhzadeh et al., 2021; Vishvkarma et al., 2020).

The main viral mechanisms that affect reproduction are the direct invasion of germ cells and dissemination via sex, attack on the endocrine reproductive system, necessary to maintain secondary sexual characteristics, inflammatory response induced by a secondary viral infection that seriously affects the testes and fever that interferes in normal reproductive phy siology (Tian et al., 2021).

Such mechanisms coexist and have a synergistic effect. In addition, the male reproductive system can be affected by antiviral drugs, due to their gonadotoxic effects, such as glucocorticoids and interferons (Tian et al., 2021).

After analyzing more than 3,800 articles, scientists found evidence that at least 11 viruses live in the testis, including those that cause pneumonia, dengue and extreme acute respiratory syndrome. However, the degree of reproduction and infection within sperm and germ cells remains unknown (Vishvkarma et al., 2020). 


\section{Epidemiology}

Sars-CoV-2 belongs to the group of Betacoronaviruses, has a predominance through the respiratory tract, is transmitted from person to person by droplets and has a higher prevalence, susceptibility and lethality in males (Illiano et al., 2020).

It affects all age groups, being more common in the elderly or people with previous comorbidities, cardiovascular and respiratory diseases, diabetes mellitus, systemic arterial hypertension and neoplasms (Segars et al., 2020).

The testicular expression of the ACE2 showed is related to age, with a greater probability of suffering a testicular injury due to COVID-19 between 20-30 years, while patients aged 60 years or more have reduced levels of expression (Dutta $e t$ al., 2021; Bahadur et al., 2020).

A systematic review that included 48 studies showed that males are more likely to suffer or die from complications of COVID-19. It was also observed that the majority of men with the disease were of childbearing age (Younis et al., 2020).

Besides that, the COVID-19 pandemic produces ethical dilemmas for the healthcare system, managers and healthcare equipment suppliers. The most difficult one is how to equitably distribute scarce resources, which can determine who lives and who dies (Monte et al., 2020).

Shastri et al. assessed the time of viral elimination after infection and noted that women can achieve earlier immunity rates than men. To determine the reason for the finding, it was found that the expression of ACE2 was in greater concentration in the testicular tissue compared to the analyzed ovaries (Efremov et al., 2020; Vishvkarma et al., 2020).

Following this same line of thought, Renu et al. demonstrated that while many carriers of the disease are asymptomatic, the deleterious reproductive effects in the infected man can be silent and, thus, make these conditions more serious due to a late diagnosis (Renu et al., 2020).

Finally, despite the foregoing, currently, the diagnostic analysis on the sperm of non-cancer patients, patients in the postoperative period of elective surgery and related fertility procedures are classified as a low priority in most countries due to the attention of the government is focused on combating the pandemic caused by COVID-19 (Hallak et al., 2020).

\section{Physiopathology}

ACE2 is a transmembrane zinc metallopeptidase, which is homologous to classic ACE, containing a single catalyst. Both are part of the renin-angiotensin-aldosterone system, which plays a fundamental role in the regulation of blood pressure and hydroelectrolytic balance (Góes et al., 2020).

When we observe the ACE2 cell receptor and the viral nucleocapsid protein in tissue samples, we can observe that positive areas are mainly distributed in the cytoplasm of epithelial cells and the cilia of the gastrointestinal glandular epithelial cells (Bocchese et al., 2020).

ACE acts to catalyze the conversion of angiotensin I to angiotensin II (ANG II), and ACE2 is responsible for the generation of angiotensin 1-7 (ANG 1-7) from angiotensin II (Younis et al., 2020; Illiano et al.,2020; Dutta et al., 2021; Sheikhzadeh et al., 2021).

While ANG II exerts deleterious effects via type 1 angiotensin II receptors, the ANG 1-7 receptor axis causes benefits, balancing and salutary actions on vital organs, such as vasodilation, anti-inflammatory, anti-fibrotic, diuretic action and natriuretic. ACE2 is widely expressed in the heart, kidneys, lungs, intestines, liver and testicles (Younis et al., 2020; Illiano et al.,2020; Dutta et al., 2021; Sheikhzadeh et al., 2021).

The cells with greater expression of ACE2 function as a key receptor for Sars-CoV-2, therefore favoring a greater predisposition to infection by COVID-19 (Illiano et al., 2020 ; Sheikhzadeh et al., 2021). The innovation in male fertility research is because the testicular Leydig and Sertoli cells have one of the largest amounts of ACE2 among the various tissues of the body, 
combined with the property of being the meeting point of most testicular mRNAs, mainly in Leydig cells (Younis et al., 2020; Vishvkarma et al., 2020).

SARS-CoV-2 activates sensitive pathways through an inflammatory response with the release of cytokines, C reactive protein (CRP), interleukin 6, procalcitonin and ferritin. This immune response is the cause of the "cytokine storm", responsible for severe lung injury, microthrombosis, and disseminated vascular coagulation (Dantas, et al.,2021). Besides that, induces oxidative stress in host tissues and affects semen quality. In addition, the coronavirus causes orchitis and psychological stress, which are among the main causes of male infertility (Olaniyan et al.,2020; Dutta et al., 2021).

In this sense, patients surviving the COVID-19 infection are at risk of infertility due to testicular atrophy, hypothalamic pathology, pituitary abnormalities and disturbance of the sexual hormonal profile (Selvaraj et al., 2021).

Recent sequencing of human sperm has demonstrated the presence of ACE2 transcription, validating its expression in germ cells, spermatocytes and round spermatids. The testicles are the male gonads responsible for the production of sperm, where the haploid germ cell and the male reproductive hormone (testosterone) are generated (Olaniyan et al., 2020). Therefore, it is observed that the virus is capable of having the enzymatic potential as a form of penetrating the male reproductive system (Younis et al., 2020; Vishvkarma et al., 2020; Fu et al., 2020).

The main types of testicular cells with ACE2 expression in the messenger RNA (mRNA) strand are the seminiferous duct cells, spermatogonia, Leydig cells and Sertoli cells (Younis et al., 2020). The difference in ACE2 levels between testicles and ovaries means being able to withstand greater vulnerability of deficiency mediated by Sars-CoV-2 in male gonadal functions (Dutta et al., 2021; Illiano et al., 2020; Sheikhzadeh et al., 2021; Fu et al., 2020).

Research carried out after the Sars-CoV outbreak in 2002, found that orchitis was one of the complications linked to the interruption of spermatogenesis and apoptosis of germ cells, affecting semen quality. In this study, histopathological investigations revealed inflammatory infiltrates in the seminiferous tubules (Dutta et al., 2021).

It is worth mentioning that in situ hybridizations of testicular tissue specimens do not recognize viral genomic materials. In addition, studies have not yet found viral traces in seminal plasma, thus indicating that inflammatory and immunological reactions play a key role in virus-mediated testicular damage (Dutta et al., 2021).

The IL-6 promotes inflammation, immune response and is associated with the pathogenesis of autoimmune orchitis. The most serious cases of COVID-19 are accompanied by a high level of IL-6, with receptors expressed in testicular cells, which justifies male gonadal involvement and the appearance of orchitis as a complication of Sars-CoV-2 (Renu et al., 2020; Haghpanah et al., 2021).

Clinical and experimental studies have associated hypogonadism with high levels of pro-inflammatory cytokines, IL1 $\beta$, IL-6 and TNF- $\alpha$, which in turn are important inflammatory mediators in the pathogenesis of Sars-CoV-2 (Dutta et al., 2021).

However, an acute critical inflammatory condition, as in the case of COVID-19, can suppress the activity of the hypothalamic-pituitary-testicular axis (HPT), reduced luteinizing hormone (LH), follicle-stimulating hormone (FSH) and levels of testosterone $(\mathrm{T})$ as one of the determining factors for the relationship of infertility associated with a viral infection (Selvaraj et al., 2021).

A study involving 81 male patients with COVID-19 demonstrated lower levels of serum testosterone (T) and higher levels of LH with a lower T: LH ratio compared to the control group of the same age, suggesting that the coronavirus may cause male hypogonadism. These findings suggest direct effects of Sars-CoV-2 infection on testicular cells instead of the HPT axis (Dutta et al., 2021; Liu et al.,2020).

An additional factor about COVID-19 and which affects male fertility is fever, as the increase in testicular temperature is harmful to spermatogenesis. In addition, there are immunomodulatory therapies with long-term effects on fertility because the 
testicular microenvironment of modified cytokines has adverse and even neoplastic effects at the cellular level, eventually favoring the emergence of testicular cancer, a second reason for long-term warning (Younis et al., 2020).

In the same context, another study carried out in Germany showed that patients with moderate infection have a statistically significant deficiency in sperm quality (concentration, total number of sperm by ejaculation, progressive immobility and incomplete motility), compared to men who had an infection and patients in the control group (Holtmann et al., 2020).

In contrast to the above, a study carried out in Wuhan, China, between January and March 2020, analyzed 34 male patients, all symptomatic for COVID-19 and RT-PCR positive, with an average age of 37 years. It was observed that six of these patients had scrotal discomfort at the time of confirmation, suggestive of orchitis, and a careful genitourinary examination was not performed. In the end, the presence of Sars-CoV-2 has not been detected in any semen sample ejaculated after 31 days of infection (Pan et al., 2020).

It is important to highlight the role of Protease Transmembrane Serine 2 (TMPRSS2) as one of the sites of invasion by SARS-CoV-2, with an expression similar to ACE2, present in the luminal cells of the prostate and released in the seminal fluid as part of the prostates. Evidence suggests that it is a regulatory factor for maintaining normal reproductive health function, with a significant role in sodium epithelial homeostasis, angiogenesis and tubulogenesis through its proteolytic cascades (Dutta et al., 2021; Sheikhzadeh et al., 2021).

Despite the inconsistent level of expression of TMPRSS2 in the male genitalia, its presence was recorded in the prostate, seminal vesicles and testicles. This discovery exposes the mechanism of invasion and vulnerability of the male reproductive tract by Sars-CoV-2 and provides the basis for further investigation into the problem in question (Sheikhzadeh et al., 2021; Fu et al., 2020).

\section{Clinical presentation}

The inhaling droplets containing the virus is how the infection is acquired. Besides that, the virus can remain alive on surfaces for a long time. The viral particles can be detected in the feces, making fecal-oral transmission possible. About the incubation period, it varies from 7 to 14 days. (Bocchese et al., 2020)

When analyzing the clinical picture, the individual infected with the new coronavirus may be asymptomatic or evolve from mild to severe intensity, being cough, fatigue, fever, headache, anosmia, ageusia, breathing difficulties and muscle pain, diarrhea and lymphopenia, most prevalent signs and symptoms (Batiha et al., 2020). An atypical presentation occurs in male patients who may experience pain and testicular edema, with potential for testicular damage and infertility (Olaniyan et al., 2020).

Treatment for COVID-19 involves, among other drugs, the use of antiviral medications such as ribavirin. However, it is known to induce oxidative stress, reduce testosterone levels and alter normal sperm characteristics. Thus, extra care is needed when prescribing it, associating risk factors and benefits (Selvaraj et al., 2021; Li et al., 2020).

Ribavirin combined with interferon can affect male fertility from a decrease in sperm count. In addition, the drug causes sperm DNA fragmentation for up to 8 months, so that contraception is performed after antiviral treatment (Li et al., 2020).

Still, about pharmacological treatment, glucocorticoids can expand the interstitial space of the spermatogenic epithelium, destroying cellular connections and affecting the blood-testicular barrier, in such a way that they allow the entry of harmful substances in the testis. However, glucocorticoids are used in small doses for a short period in the management of COVID, thus having a minimal impact on the reproductive system (Li et al., 2020).

Cryopreservation and sperm donation amid the COVID-19 pandemic is another therapeutic option that may have an impact on the maintenance of semen in cancer patients, highlighting the need to resume fertility services. However, there is still 
no study on the quality of semen after infection by Sars-CoV-2, but it is known that periods of stress increase the concentration of cortisol, which is responsible for interfering negatively in this variable (Illiano et al., 2020).

It is important to highlight the role of the brain related to fertility in patients with Sars-CoV-2. Most viruses enter the human body through the nasal and oral pathways, crossing the central nervous system (CNS), reproducing and dispersing through the olfactory bulb, lingual nerve or vagus nerve (Vishvkarma et al., 2020). In addition, even if it does not cross the blood-brain barrier, Sars-CoV-2 induces an immune reaction that activates the cascade of inflammatory cytokines, and therefore brings harmful consequences to fertility as highlighted earlier (Vishvkarma et al., 2020).

The inflammatory process occurs in several anatomical sites of the CNS such as meninges, brain, spinal cord and in other different regions causing meningitis, encephalitis, myelitis and more serious conditions such as meningoencephalitis or encephalomyelitis. Besides that, patients with COVID-19 can have neurological syndromes, loss of involuntary breathing process, impairment of the brainstem, ataxia, loss of smell, seizures, among others. These manifestations, however, are signs of a worse prognosis (Góes et al., 2020). In addition, it was observed that brain cells express ACE2 receptors in glial cells and neurons, making them a possible target for Sars-CoV-2 and, consequently, a potential risk factor for male infertility (Vishvkarma et al., 2020).

\section{Infertility}

Infertility, in turn, is considered the most serious reproductive disorder and in $25 \%$ of cases it is idiopathic (Shen et al., 2020). Over the years, its possible causes have been identified in pre-existing associated pathologies, such as changes in the immune system (such as viral infections), thyroid dysfunctions and coagulopathies (Pacchiarotti et al., 2020).

In addition, the relationship between the environment and reproductive capacity has proven to have a direct association. Studies have shown that stress is associated with changes in eating habits and exercise, resulting in a set of variables that favor reproductive disorders. The diagnosis is based on the exclusion of common causes, using the investigation of the fertility pattern (Pacchiarotti et al., 2020).

An important aspect of COVID-19 is the duration of disease morbidity in activity, with a median of 22 days and the high degree of the immune response, which affects the organs that express ACE2 receptors, including the testicles (Li et al., 2020; Vishvkarma et al., 2020).

\section{Psychosocial aspects}

In addition to the pathophysiological aspects, the pandemic caused a severe economic recession, an increase in the unemployment rate and, consequently, a decline in the birth rate, considering that several couples are no longer able to financially support their offspring (Trinchant et al, 2020).

When it comes to mental health, reproductive health in humans depends on a huge range of factors, including physical, mental and social health. The current pandemic status of COVID-19, as well as its treatment, prevention and control measures associated with it, causes an exacerbated concern about the disease, culminating in a state of panic, depression, anxiety, fear and post-traumatic stress disorders, which, consequently, affects the reproductive health of people, infected or not (Li et al.,2020; Esposito et al., 2020; Liu et al., 2020).

Elevated stress levels disrupt homeostasis, activating the central stress response system, which results in deregulation of the hypothalamic-pituitary-adrenal axis and inhibits reproductive function. In addition, the decrease in fertility during the period of psychological crisis is related to the reduction of sperm quality and an induced sexual dysfunction, as well as affecting seminal parameters (Li et al., 2020). 
Veronica Esposito et al. directed his study to investigate psychological aspects of infertile couples, in order to better understand the level of suffering. As a result, there was a noticeable increase in the number of cases of depression and anxiety, with an incidence of $75 \%$ and $71 \%$ of the scores in the Impact of Event Scale - Review (IES-R) and State-Trait Anxiety Inventory (STAI), respectively (Esposito et al., 2020).

Based on the association of increased unemployment with male infertility, the turnaround in social life is notorious, damaging intellectuality, humor and life prospects (Esposito et al., 2020; Shen et al., 2020).

"The Lancet Psychiatry" recently discussed the current pandemic situation and highlighted the rise in suicide rates. The more the disease spreads, the more long-term effects can be felt in different areas of life, generating a greater impact on populations considered vulnerable, such as men susceptible to infertility, and therefore contributing to the increase in suicidal behavior rates (Shen et al., 2020).

\section{Conclusion}

In conclusion, considering that infertility in men is already a worldwide trend and a serious threat to humanity, understanding the effects of Sars-CoV-2 on testicular physiology has become an important and necessary public health responsibility, and it is crucial to carry out more studies to reveal the exact impact and the mechanisms by which COVID-19 operates in this field of science.

Unfortunately, the most recent primary studies have limitations in terms of small sample size, testing methods and the course of the disease, which directly interfere in proving the hypotheses. Additional analyzes are necessary to confirm the results and evaluate the prevention of testicular damage, as well as the possibility of reversal of the condition, in addition to tracking reproductive functions in men who are victims of the disease.

It is essential that health professionals pay more attention to male genital examinations, in addition to the organs primarily involved, with an effective investigation, evaluation and intervention, during or even after the pandemic, to recognize important signs and symptoms of the respective clinical condition.

Finally, it is possible to affirm, undoubtedly, that the psychobiological consequences of the pandemic in infertile patients should not be underestimated. In this sense, it is vital to offer prior guidance, psychological support and individualized action planning, taking into account all the variables involved in this important and complex process that is male fertility.

With a view to the future and increasing evidence on this topic, better research such as randomized trials and systematic reviews with meta-analysis are essential to obtain an effective understanding of the relationship between male infertility and a COVID-19. Thus, it is important to establish segments in the scientific literature, aiming to avoid relevant transformations in the clinical-clinics of the subject addressed.

\section{References}

Bahadur, G., Acharya, S., Muneer, A., Huirne, J., Łukaszuk, M., Doreski, P. A., \& Homburg, R. (2020). SARS-CoV-2: diagnostic and design conundrums in the context of male factor infertility. Reproductive biomedicine online, 41(3), 365-369. https://doi.org/10.1016/j.rbmo.2020.05.014.

Batiha, O., Al-Deeb, T., Al-Zoubi, E., \& Alsharu, E. (2020). Impact of COVID-19 and other viruses on reproductive health. Andrologia, 52(9), e13791. https://doi.org/10.1111/and.13791.

Bocchese, N. V., Dávila, N. G., Rodrigues, M. B. M., Araújo-Neto, I., Costa, M. O., Barbalho, D. M. G., Rêgo, A. C. M., \& Araújo-Filho, I. (2020). COVID-19 and Liver Injury: Hepatology Perspectives. Journal of Clinical Gastroenterology and Treatment, 6(074), 1-5. https://doi.org/10.23937/2469-584X/1510074.

Bocchese, N. V., Dávila, N. G., Rodrigues, M. B. M., Monte, R. R. L., Melo, R. C., Rêgo, A. C. M., \& Araújo-Filho, I. (2020). Covid-19: Gastroenterology Perspectives. Journal of clinical gastroenterology and treatment, 6(075), 1-8. https://doi.org/10.23937/2469-584X/1510075

Dantas, T. C; Gomes, A. C. A.; Lima, I. P. C; Lucas, B. B; Aguiar, M. R; Cavalcanti, T. C; Pinheiro, F. I.; Rêgo, A. C. M; Araújo-filho, I. Corticosteroid therapy in patients with severe COVID-19. Research, Society and Development, [S. l.], v. 10, n. 1, p. e58910112114, 2021. DOI: 10.33448/rsd-v10i1.12114. Disponível em: https://rsdjournal.org/index.php/rsd/article/view/12114. Acesso em: 11 may. 2021. 
Dutta, S., \& Sengupta, P. (2021). SARS-CoV-2 and Male Infertility: Possible Multifaceted Pathology. Reproductive sciences (Thousand Oaks, Calif.), 28(1), 23-26. https://doi.org/10.1007/s43032-020-00261-z.

Efremov, E. A., Kasatonova, E. V., Melnik, Y. I., \& Nikushina, A. A. (2020). Urologiia (Moscow, Russia : 1999), (4), 104-110. PMID: 32897023.

Esposito, V., Rania, E., Lico, D., Pedri, S., Fiorenza, A., Strati, M. F., Conforti, A., Marrone, V., Carosso, A., Revelli, A., Zullo, F., Di Carlo, C., \& Venturella, R. (2020). Influence of COVID-19 pandemic on the psychological status of infertile couples. European journal of obstetrics, gynecology, and reproductive biology, 253, 148-153. https://doi.org/10.1016/j.ejogrb.2020.08.025.

Fu, J., Zhou, B., Zhang, L., Balaji, K. S., Wei, C., Liu, X., Chen, H., Peng, J., \& Fu, J. (2020). Expressions and significances of the angiotensin-converting enzyme 2 gene, the receptor of SARS-CoV-2 for COVID-19. Molecular biology reports, 47(6), 4383-4392. https://doi.org/10.1007/s11033-020-05478-4.

Goés, A. B. M., Cardoso, B. B., Tavares, F. A. F., Monte, R. R. L., Melo, R. C., Araújo-Neto, I., Pinheiro, R. S. E., Rêgo, A. C. M., \& Araújo-Filho, I. (2020) COVID-19 and Nervous System: Under Estimated Clinical and Prognostic Aspects. International journal of neurology and neurotherapy, 7(100), 1-7. https://doi.org/10.23937/2378-3001/1410100.

Haghpanah, A., Masjedi, F., Alborzi, S., Hosseinpour, A., Dehghani, A., Malekmakan, L., \& Roozbeh, J. (2021). Potential mechanisms of SARS-CoV-2 action on male gonadal function and fertility: Current status and future prospects. Andrologia, 53(1), e13883. https://doi.org/10.1111/and.13883.

Hallak, J., \& Esteves, S. C. (2020). Concise practice recommendations for the provision of andrological services and assisted reproductive technology for male infertility patients during the SARS-CoV-2 in Brazil. International braz $j$ urol : official journal of the Brazilian Society of Urology, 46(6), 1082-1089. https://doi.org/10.1590/S1677-5538.IBJU.2020.06.03.

Holtmann, N., Edimiris, P., Andree, M., Doehmen, C., Baston-Buest, D., Adams, O., Kruessel, J. S., \& Bielfeld, A. P. (2020). Assessment of SARS-CoV-2 in human semen-a cohort study. Fertility and sterility, 114(2), 233-238. https://doi.org/10.1016/j.fertnstert.2020.05.028.

Illiano, E., Trama, F., \& Costantini, E. (2020). Could COVID-19 have an impact on male fertility? Andrologia, 52(6), e13654. https://doi.org/10.1111/and.13654

Li, R., Yin, T., Fang, F., Li, Q., Chen, J., Wang, Y., Hao, Y., Wu, G., Duan, P., Wang, Y., Cheng, D., Zhou, Q., Zafar, M. I., Xiong, C., Li, H., Yang, J., Qiao, J. Potential risks of SARS-CoV-2 infection on reproductive health. Reprod Biomed Online. 2020 Jul;41(1):89-95. doi: 10.1016/j.rbmo.2020.04.018.

Li, X. P., Zhang, Y. D., Xia, K., Liu, G. H., \& Deng, C. H. (2020). Zhonghua nan ke xue = National journal of andrology, 26(3), 215-218. PMID: 33346959.

Liu, X., Chen, Y., Tang, W., Zhang, L., Chen, W., Yan, Z., Yuan, P., Yang, M., Kong, S., Yan, L., \& Qiao, J. (2020). Single-cell transcriptome analysis of the novel coronavirus (SARS-CoV-2) associated gene ACE2 expression in normal and non-obstructive azoospermia (NOA) human male testes. Science China. Life sciences, 63(7), 1006-1015. https://doi.org/10.1007/s11427-020-1705-0.

Monte, R. R. L., Tavares, F. A. F., Cardoso, B. B., Goes, A. B. M., Silva, T. C. L., Silva, B. O., Araújo, Y. S. M., Rêgo, A. C. M., \& Araújo-Filho, I. (2020) Covid-19 Pandemic and Health Professionals: Practical Approaches. International Journal of Critical Care and Emergency Medicine, 6(108), 1-9. https://doi.org/10.23937/2474-3674/1510108.

Olaniyan, O. T., Dare, A., Okotie, G. E., Adetunji, C. O., Ibitoye, B. O., Bamidele, O. J., \& Eweoya, O. O. (2020). Testis and blood-testis barrier in Covid-19 infestation: role of angiotensin-converting enzyme 2 in male infertility. Journal of basic and clinical physiology and pharmacology, 31(6). https://doi.org/10.1515/jbcpp-2020-0156.

Pacchiarotti, A., Frati, G., \& Saccucci, P. (2020). A surprising link with unexplained infertility: a possible Covid-19 paradox? Journal of assisted reproduction and genetics, 37(11), 2661-2662. https://doi.org/10.1007/s10815-020-01911-6.

Pan, F., Xiao, X., Guo, J., Song, Y., Li, H., Patel, D. P., Spivak, A. M., Alukal, J. P., Zhang, X., Xiong, C., Li, P. S., \& Hotaling, J. M. (2020). No evidence of severe acute respiratory syndrome-coronavirus 2 in semen of males recovering from coronavirus disease 2019. Fertility and sterility, 113(6), 1135-1139. https://doi.org/10.1016/j.fertnstert.2020.04.024.

Pereira, A. S., Shitsuka, D. M., Parreira, F. J., \& Shitsuka, R. (2018). Metodologia Da Pesquisa Científica (1st ed.). Santa Maria: Universidade Federal de Santa Maria.

Renu, K., Subramaniam, M. D., Chakraborty, R., Myakala, H., Iyer, M., Bharathi, G., Siva, K., Vellingiri, B., \& Valsala Gopalakrishnan, A. (2020). The role of Interleukin-4 in COVID-19 associated male infertility - A hypothesis. Journal of reproductive immunology, 142, 103213. https://doi.org/10.1016/j.jri.2020.103213.

Segars, J., Katler, Q., McQueen, D. B., Kotlyar, A., Glenn, T., Knight, Z., Feinberg, E. C., Taylor, H. S., Toner, J. P., Kawwass, J. F., \& American Society for Reproductive Medicine Coronavirus/COVID-19 Task Force (2020). Prior and novel coronaviruses, Coronavirus Disease 2019 (COVID-19), and human reproduction: what is known? Fertility and sterility, 113(6), 1140-1149. https://doi.org/10.1016/j.fertnstert.2020.04.025.

Selvaraj, K., Ravichandran, S., Krishnan, S., Radhakrishnan, R. K., Manickam, N., \& Kandasamy, M. (2021). Testicular Atrophy and Hypothalamic Pathology in COVID-19: Possibility of the Incidence of Male Infertility and HPG Axis Abnormalities. Reproductive sciences (Thousand Oaks, Calif.), 1-8. Advance online publication. https://doi.org/10.1007/s43032-020-00441-x.

Sheikhzadeh Hesari, F., Hosseinzadeh, S. S., \& Asl Monadi Sardroud, M. A. (2021). Review of COVID-19 and male genital tract. Andrologia, 53(1), e13914. https://doi.org/10.1111/and.13914.

Shen, Q., Xiao, X., Aierken, A., Yue, W., Wu, X., Liao, M., \& Hua, J. (2020). The ACE2 expression in Sertoli cells and germ cells may cause male reproductive disorder after SARS-CoV-2 infection. Journal of cellular and molecular medicine, 24(16), 9472-9477. https://doi.org/10.1111/jcmm.15541.

Tian, Y., \& Zhou, L. Q. (2021). Evaluating the impact of COVID-19 on male reproduction. Reproduction (Cambridge, England), 161(2), R37-R44. https://doi.org/10.1530/REP-20-0523. 
Research, Society and Development, v. 10, n. 6, e46510616059, 2021 (CC BY 4.0) | ISSN 2525-3409 | DOI: http://dx.doi.org/10.33448/rsd-v10i6.16059

Trinchant, R. M., Cruz, M., Marqueta, J., \& Requena, A. (2020). Infertility and reproductive rights after the COVID-19 pandemic. Reproductive biomedicine online, 41(2), 151-153. https://doi.org/10.1016/j.rbmo.2020.05.007.

Vishvkarma, R., \& Rajender, S. (2020). Could SARS-CoV-2 affect male fertility? Andrologia, 52(9), e13712. https://doi.org/10.1111/and.13712.

Younis, J. S., Abassi, Z., \& Skorecki, K. (2020). Is there an impact of the COVID-19 pandemic on male fertility? The ACE2 connection. American journal of physiology. Endocrinology and metabolism, 318(6), E878-E880. https://doi.org/10.1152/ajpendo.00183.2020. 